\title{
Bibliometric Analysis of COVID-19 Publications in the Field of Chest and Infectious Diseases
}

\author{
Göğüs ve Enfeksiyon Hastalıkları Alanındaki COVID-19 Yayınların Bibliyometrik Analizi
}

\author{
Pinar YILDIZ GÜLHAN ${ }^{1}$ \\ (D) 0000-0002-5347-2365 \\ Mehmet Nurullah KURUTKAN ${ }^{2}$ \\ (D) 0000-0002-3740-4231
}

\begin{abstract}
Aim: At the context of the chest and infectious diseases, the main goal of this study is to make a bibliometric analysis of publications on coronavirus disease 2019 (COVID-19). Visualizing it with visible and scientific mapping techniques is the secondary goal.

Material and Methods: Raw data for 2020 have been downloaded from the Web of Science Core Collection database. A total of 787 articles were reviewed. Raw data were analyzed with Bibliometrix and VOSviewer. The articles about COVID-19, related with the respiratory system and infectious diseases were included. The perspectives of other disciplines were excluded with the analysis.

Results: A total of 787 articles were published in 108 different journals. The average number of citations per article is 10.17 . There are four studies with over 300 citations. The top three authors with the highest $\mathrm{H}$ index are Raoult $\mathrm{D}$, Colson $\mathrm{P}$ and Rolasin JM. The $\mathrm{h}, \mathrm{g}$ and $\mathrm{m}$ indices of the authors were calculated and the core authors were determined according to Lotka's law. The top three countries that publish the most articles are China, America and Italy. Finally, according to the word mining analysis, it was determined that the studies can be classified under three clusters.

Conclusion: One of the tools that will accelerate the basic reading process in the face of the numerical increase rate of publications on COVID-19 is the bibliometric analysis results. The most up-to-date and basic information on treatment options can be found collectively in bibliometric studies.

Keywords: Bibliometric; COVID-19; infectious diseases; respiratory system.
\end{abstract}

${ }^{1}$ Düzce University Faculty of Medicine Department of Chest Diseases, Düzce, Turkey

${ }^{2}$ Düzce University Faculty of Management Department of Healthcare Management, Düzce, Turkey

\section{Corresponding Author Sorumlu Yazar \\ Pınar YILDIZ GÜLHAN}

pinaryildiz691@hotmail.com

Received / Geliş Tarihi : 25.11.2020 Accepted / Kabul Tarihi : 11.03.2021 Available Online /

Çevrimiçi Yayın Tarihi : 22.03.2021
ÖZ

Amaç: Bu çalışmanın temel amacı, göğüs hastalıkları ve enfeksiyon hastalıkları alanında, koronavirüs hastalığı 2019 (coronavirus disease 2019, COVID-19) ile ilgili yayınların bibliyometrik analizini yapmaktır. İkincil amaç ise yayınların analizini görsel ve bilimsel haritalama teknikleriyle görselleştirmektir.

Gereç ve Yöntemler: 2020 y1lına ait ham veriler, Web of Science Core Collection veri tabanından indirilmiştir. Toplamda 787 makale gözden geçirilmiştir. Ham veriler Bibliometrix ve VOSviewer yazılımları ile analiz edilmiştir. COVID-19 ile ilgili makalelerin sadece solunum sistemi ve enfeksiyon hastalıkları ile ilgili olanları bu analize dahil edilmiştir. Diğer disiplinlere ait bakış açıları ise analize dahil edilmemiştir.

Bulgular: Toplam 787 makale 108 farklı dergide yayınlanmıştır. Makale başına düşen ortalama atıf sayısı 10,17 'dir. 300'ün üzerinde atıf alan dört adet çalışma bulunmaktadır. H indeksi en yüksek olan ilk üç yazar Raoult D, Colson P ve Rolasin JM olarak tespit edilmiştir. Yazarların h, g ve $\mathrm{m}$ indeksleri hesaplanmış ve Lotka yasasına göre core yazarlar tespit edilmiştir. En fazla yayın yapan ülkeler için ilk üç sırada Çin, Amerika ve İtalya yer almaktadır. Son olarak kelime madenciliği analizine göre çalışmaların üç küme altında sınıflandırılabileceği tespit edilmiştir. hızlandıracak araçlardan biri de bibliyometrik analiz sonuçlarıdır. Tedavi seçenekleriyle ilgili en güncel ve temel bilgiler topluca bibliyometrik çalışmalarda bulunabilir.

Anahtar kelimeler: Bibliyometri; COVID-19; enfeksiyon hastalıkları; solunum sistemi.

$\overline{\text { Presented as an oral presentation at TÜSAD SOLUNUM } 2020 \text { Digital Congress (October 2-8, 2020) }}$
Sonuç: COVID-19 ile ilgili yayınların sayısal artış hızı karşısında temel okuma sürecini 


\section{INTRODUCTION}

The severe acute respiratory syndrome coronavirus 2 (SARS-CoV-2) infection outbreak has been named coronavirus disease 2019 (COVID-19) by the World Health Organization (WHO). COVID-19 spread rapidly too many countries and was officially declared a pandemic by the WHO on March 11, 2020, with more than 4,000 deaths. (1). COVID-19 is caused by a new coronavirus first identified in Wuhan, China, in December 2019. The disease is highly contagious and its main clinical symptoms are fever, dry cough, fatigue, muscle pain, and shortness of breath $(1,2)$.

The diagnosis is made by clinical and laboratory methods. There is no proven specific treatment. Vaccine studies are ongoing (3). Physicians treating patients with COVID-19 disease; uses different antivirals and anti-inflammatory agents and tries to manage the disease based on expert opinions, case series and prospective and randomized studies reported from all over the world (4).

Bibliometry is a statistical method that can perform quantitative analysis of research articles on a particular subject in mathematical ways. It can also access the quality of studies, analyze key areas of research and predict the direction of future studies. Since the COVID-19 pandemic is not completely under control, its bibliometric analysis is a critical need (5).

Bibliometry is a branch of information science and bibliometric methods are effective tools developed for assessing the particular aspects of research or the values of a particular journal $(6,7)$. With bibliometric methods, the evolution of a research direction can be revealed because bibliometry consists of the combination of linguistics, information and statistical sciences in a given field (8).

Bibliometry with science mapping and visual mapping tools (9) has been applied to many research areas such as engineering, road safety (10), assessment of social life cycle (9), financial performance (11) and the re-planning of higher education (12).

Thanks to bibliometry, a picture of the development process of a journal can be drawn. For example, the development process of a journal, effectivity, the total number of publications (TP), and total citations (TC), the average number of citations per publication (AC), and some generally accepted bibliometric indicators such as $\mathrm{h}$ index, $\mathrm{g}$ index and $\mathrm{m}$ index can be evaluated with some generally accepted bibliometric indicators $(13,14)$.

Visualization is an important technique for bibliometric analysis. Academicians can visually analyze the structure and trend of a research area or journal with bibliometric tools (15). Free softwares such as Bibliometrix (16), VoSviewer (17), CiteSpace (18) and SciMAT (19) have become popular tools in the bibliometric analysis since they have a powerful user graphical interface and map visualization capability. Many studies use the above softwares separately: Bibliometrix has been used on topics such as political marketing (20), social responsibility of universities (21), health policy (22), and cyber behaviour (23). VoSviewer, CiteSpace and SciMAT have been used in many fields such as food chemistry (24), emergency medicine (25), information literacy assessment (26) and COVID-19 (27).

There are many bibliometric analysis studies on COVID-19; Zhou et al. (28) in 2020, conducted a study for the entire coronavirus family based on the last twenty years. As the key finding, they clarified the finding that studies increased after SARS and MERS outbreaks. In a study by Kaya et al. (29), all studies published in the first four months of 2020 were examined. They drew attention to international cooperation between the authors. Ram (30), in 2020, has studied the last 50 years of studies for the whole coronavirus family. He examined the performance of the publications in terms of the country, the university, and the most publishing magazine. In another study, Nasab et al. (31) examined the publications in the first three months of 2020 in terms of key performance indicators. In this study, the general search strategy was not set up and the issue of COVID-19 was examined in terms of respiratory diseases and infectious diseases. When the previous studies are examined, it is seen that the publications either point to the early period (first three and fourth months of 2020) or the last 20 and last 50 years of the whole coronavirus family have been examined. There is a need for a study that examines COVID-19 in terms of chest diseases and infectious science and narrowly examines the performance and intellectual structure of the publications here. This study demonstrates the potential to be one of the studies that focus on this need. At this context of the chest and infectious diseases, the main goal of this study is to make a bibliometric analysis of publications on coronavirus disease 2019 (COVID-19). Visualizing it with visible and scientific mapping techniques is the secondary goal.

\section{MATERIAL AND METHODS}

A search was made from the Web of Science (WoS) Core Collection database (32) on August 14, 2020, with the following search strategy and the following article number was reached. The studies were filtered. Articles and reviews were chosen. The raw data were downloaded as "plain.txt". In this study, all articles and reviews from the first days of 2020 until the date of the search were included in the study. The analysis performed within the scope of the study are as shown in Table 1.

"Search Strategy: TOPIC: (COVID-19) OR TITLE:

(COVID-19 pneumonia) AND TOPIC: (treatment)

AND TOPIC: (respiratory failure) AND TOPIC:

(SARS CoV-2) Refined by: WEB OF SCIENCE

CATEGORIES: (INFECTIOUS DISEASES OR

RESPIRATORY SYSTEM) AND DOCUMENT

TYPES: (ARTICLE OR REVIEW) AND

LANGUAGES: (ENGLISH) Timespan: 2020-2020.

Indexes: SCI-EXPANDED, SSCI, A\&HCI, CPCI-S,

CPCI-SSH, BKCI-S, BKCI-SSH”.

WoS is preferred because it is one of the most common database among academics and many journals are available. WoS provides detailed information about publications (33). Three software were used in this study. There are aspects in which each software is superior to other programs. Bibliometrix, VOSviewer and CiteSpace software were used separately in this study. Bibliometrix was used for performance analysis of publications on COVID-19, VOSviewer for co-occurrence network map analysis, and CiteSpace software for co-citation analysis (usually used to reveal the intellectual structure of a discipline). See Table 1 for details of performance analyzes. 
The rest of this article is organized as follows: Part 2 focuses on the main findings. Part 3 will examine organizations such as Productivity and Collaboration Networks of Countries and Institutions. In Part 4, Major clusters, time maps and citation bursts will be examined. In Part 5, word analysis will be done by using data mining. The remaining parts are written as discussion, limitations and conclusion.

\section{RESULTS}

\section{Main Findings on COVID-19}

The COVID-19 pandemic has and continues to pose a major threat to all international societies. All research on COVID-19 disease is of great importance both for the control of the disease and for the treatment of patients. The main purpose of this study is to make a visual analysis of publications on COVID-19 in the light of science mapping techniques. In this section, general information about the type of publications between the first month of 2020 and August 21, 2020, and the most cited publications will be given.

\section{Main Statistics on Data}

A total of 787 articles and reviews were written over a period of 8 months. The number of authors is 5535 and the number of studies with a single author is 26 . The number of citations per article is 10.17 and the total number of references is 10865 . The number of authors per article is 7.03 and all data are given in Table 2 below.

\section{Best Authors and Journals}

The relationships between keywords, authors and journals of the main authors were visualized by using the Three-Fields Plot. In this analysis, it was inspired by the study of Janik et al. (34). In Three-Fields Plot, the relevant elements are represented in the diagram by rectangles of different colors. The height of the rectangle depends on the element represented by the rectangle (the author's keyword, author, and one of the elements in the source diagram) and the value of the sum of the relationships that arise between the diagrams of other items. The more relationships the item has, the higher the rectangle that represents it is depicted. Figure 1 represents the research scheme in the COVID-19 literature focusing on the relationships between the main authors' keywords, authors, and journals. The analysis showed in which journals published the most COVID-19 publication and which topics were discussed the most. Research topics were determined here as the keywords of the authors. Analysis result highlighted 3 authors (i.e. Husueh PR, Li $\mathrm{Y}$ and Wamg $\mathrm{J}$ ) and 3 journals (i.e. International Journal of Infectious Disease, International Journal of Antimicrobial Agents, and Epidemiology and Infection). In COVID-19 literature main research topics were COVID-19, SARS-CoV-2 and coronavirus disease 2019. Other information indicated in Figure 1.

Among the top three most published journals, the International Journal of Infectious Diseases has 126 publications, Eurosurveillance has 47 and Epidemiology and Infection has 35 publications (Table 3 ).

\section{Bradford's Law}

For the determination of the most basic and Wellestablished journals, only five of the journals obtained with the Biblioshiny program were found to be the core sources (Figure 2). International Journal of Infectious
Diseases, Eurosurveillance, Epidemiology and Infection, International Journal of Antimicrobial Agents, and Journal of Infection have been identified as the most important and basic journals.

\section{$H, G$ and $M$ Indexes of Journals}

The "Hirsch index" or "h-index" designed by Jorge Hirsch for micro-level application is a unique and simple performance index that includes both the quantity and

Table 1. Software and analyzes

\begin{tabular}{|c|c|}
\hline Data Source & Analysis Categories \\
\hline \multirow{8}{*}{$\begin{array}{l}\text { Bibliometrics } \\
\text { Biblioshiny }\end{array}$} & Main Statistics \\
\hline & $\begin{array}{l}\text { Total number of publications, number of } \\
\text { citations and average number of citations }\end{array}$ \\
\hline & $\begin{array}{l}\text { Productivity and Collaboration Networks of } \\
\text { Countries and Institutions } \\
\text { - Country productivity map }\end{array}$ \\
\hline & - Country cooperation map \\
\hline & - Most cited countries \\
\hline & - University citation numbers \\
\hline & - Corresponding author's Country \\
\hline & $\begin{array}{l}\text { Highly Contribute Authors Papers, Citations } \\
\text { - Top authors production over time } \\
\text { - Lotka law and Number of authors who } \\
\text { wrote the most articles } \\
\end{array}$ \\
\hline \multirow{2}{*}{ VosViewer } & Keyword co-occurrence network map \\
\hline & Density visualization \\
\hline \multirow{2}{*}{ Cite Space } & Document co-citation analysis \\
\hline & Time map of clusters \\
\hline
\end{tabular}

Table 2. Main statistics on COVID-19

\begin{tabular}{lc}
\hline Description & Results \\
\hline Main Information About Data & $2020: 2020$ \\
Timespan & 108 \\
Sources (journals, books, etc.) & 787 \\
Documents & 0 \\
Average years from publication & 10.17 \\
Average citations per documents & 11.15 \\
Average citations per year per doc & 10865 \\
References & \\
Document Types & 708 \\
Article & 78 \\
Article; early access & 1 \\
Article; proceedings paper & \\
Document Contents & 554 \\
Keywords Plus (ID) & 1447 \\
Author's Keywords (DE) & \\
Authors & 5535 \\
Authors & 6907 \\
Author appearances & 26 \\
Authors of single-authored documents & 5509 \\
Authors of multi-authored documents & \\
Authors Collaboration & 26 \\
Single-authored documents & 0.142 \\
Documents per author & 7.03 \\
Authors per document & 8.78 \\
Co-Authors per documents & 7.24 \\
Collaboration index & \\
\hline
\end{tabular}


visibility of publications. It is an author-level metric that tries to measure the productivity and citation impact of the publications made by scientists. Since h-indexes are affected by the citation traditions and methods of each discipline, it is difficult to compare this index between disciplines (35). The g-index, developed by Leo Egghe in 2006, is an alternative to the h-index that does not average citation numbers to measure the global citation performance of a series of articles. Egghe thinks that the hindex has a disadvantage that it does not take into account the citation scores of the top articles. The index is calculated based on the distribution of citations received by a particular researcher's publications. While the gindex gives more weight to articles with high citations, the $\mathrm{h}$-index is insensitive to it. It helps to make the difference between the author's related effects more distinct when calculating the performance of the author's most-read articles (36). The h-index is a less appropriate measure of academic achievement for young academics because it does not yet have enough time to cite articles. Especially in social science, it can take more than five years for an article to generate a significant number of citations. Young academics may prefer impact factor for final assessment. Dividing the h-index by the number of years the academy has been active can facilitate the comparison between academics with different lengths of academic careers. This index created by Hirsch is defined as the m-index (37). As a result, when the index scores of journals (Table 3 ) in terms of all three indicators (h-g-m index) were evaluated, there are two journals (International Journal of Infectious Diseases and Journal of Infection) with the highest scores in terms of $\mathrm{h}$ and $\mathrm{m}$ index. The journal with the highest score in terms of $G$ index is International Journal of Antimicrobial Agents.

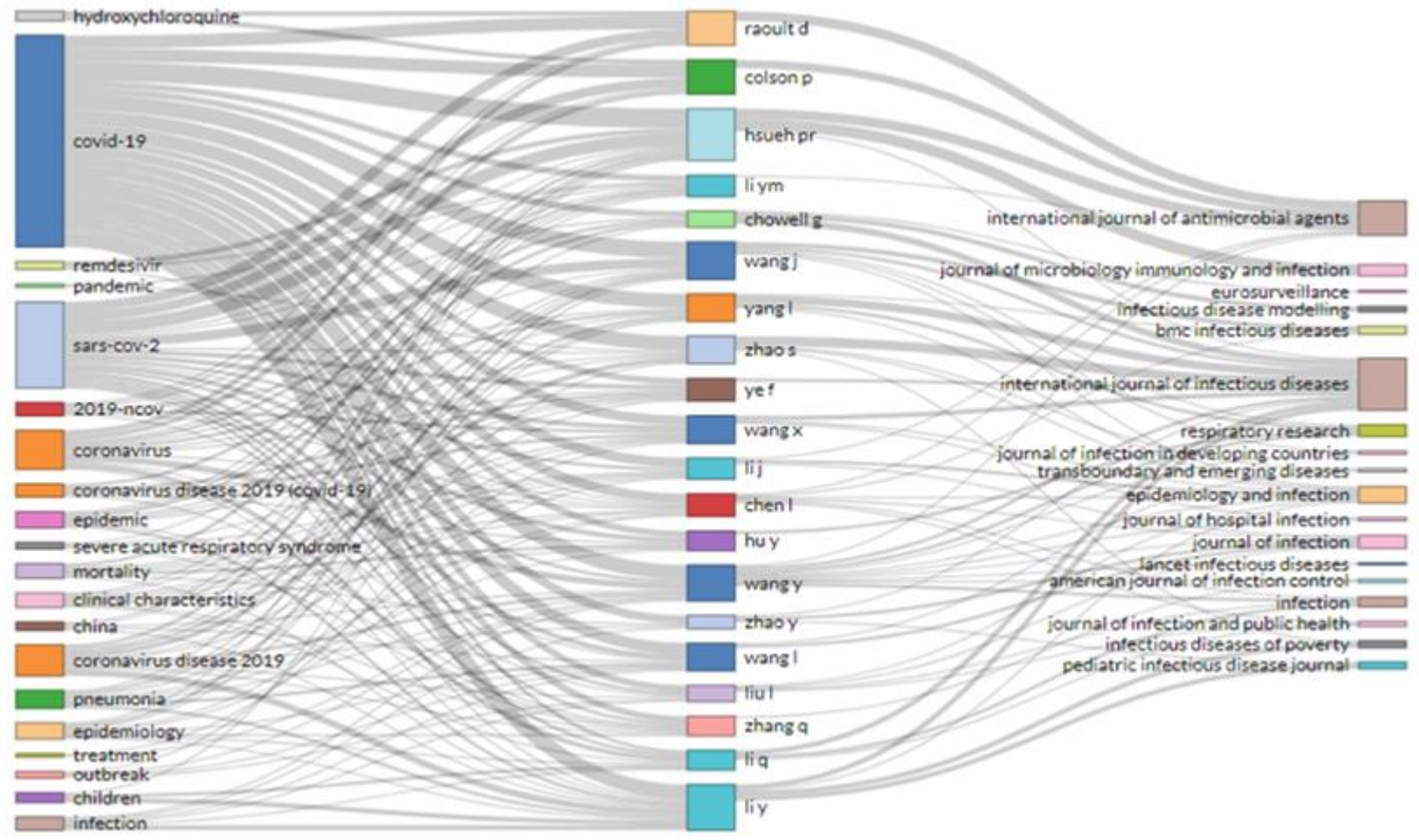

Figure 1. COVID 19 three area graph, keywords (left), authors (middle) and sources (right)

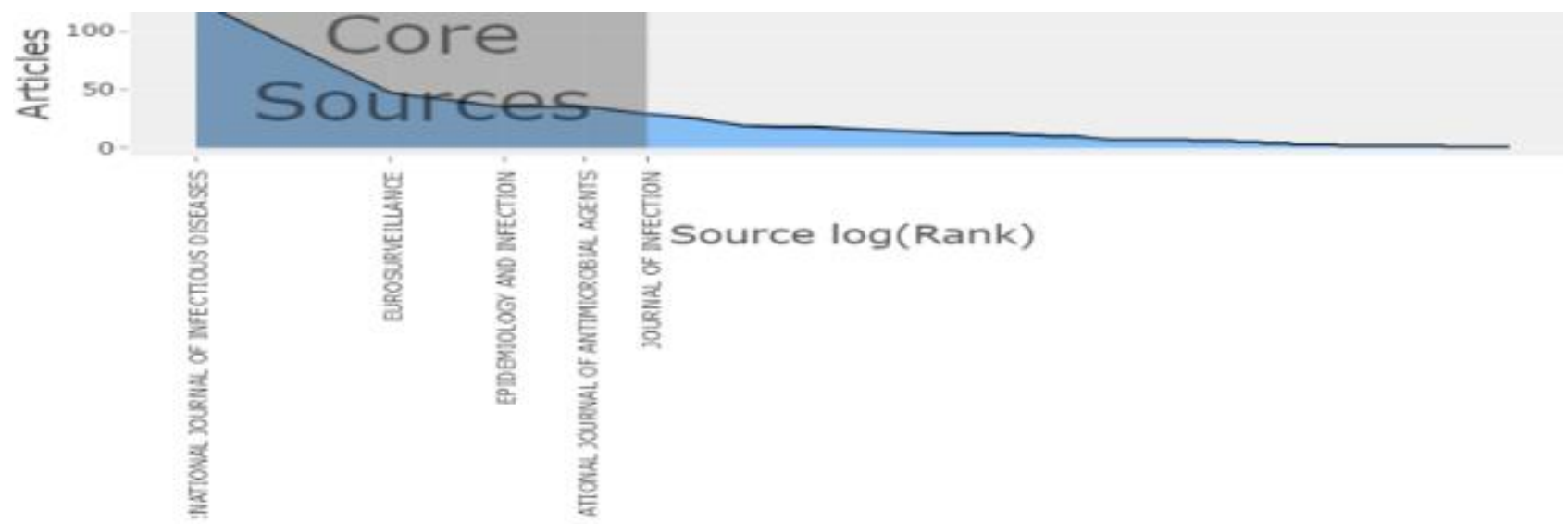

Figure 2. Bradford's law 
Table 3. Most published journals, and h, g and $\mathrm{m}$ indexes (top 20 journals)

\begin{tabular}{|c|c|c|c|c|c|}
\hline Source & TP & TC & $h$ index & g index & m index \\
\hline $\begin{array}{l}\text { International Journal of Infectious Diseases } \\
\end{array}$ & 126 & 759 & 13 & 25 & 13 \\
\hline Eurosurveillance & 47 & 411 & 8 & 19 & 8 \\
\hline Epidemiology and Infection & 35 & 24 & 2 & 4 & 2 \\
\hline International Journal of Antimicrobial Agents & 35 & 1488 & 12 & 35 & 12 \\
\hline Journal of Infection & 29 & 702 & 13 & 26 & 13 \\
\hline Transplant Infectious Disease & 25 & 13 & 1 & 3 & \\
\hline Infection & 19 & 103 & 4 & 10 & \\
\hline Infectious Disease Modelling & 18 & 103 & 5 & 10 & 5 \\
\hline Journal of Microbiology, Immunology and Infection & 18 & 172 & 6 & 12 & 6 \\
\hline Journal of Infection and Public Health & 17 & 27 & 2 & 5 & 2 \\
\hline Infectious Diseases of Poverty & 16 & 41 & 2 & 6 & 2 \\
\hline Transboundary and Emerging Diseases & 15 & 8 & 2 & 2 & \\
\hline Respiratory Research & 14 & 20 & 2 & 4 & 2 \\
\hline BMC Infectious Diseases & 13 & 13 & 2 & 3 & 2 \\
\hline American Journal of Infection Control & 12 & 10 & 2 & 3 & 2 \\
\hline Journal of Hospital Infection & 12 & 30 & 3 & 5 & 3 \\
\hline Journal of Infection in Developing Countries & 12 & 81 & 4 & 9 & 4 \\
\hline Pediatric Infectious Disease Journal & 12 & 75 & 3 & 8 & 3 \\
\hline Lancet Infectious Diseases & 11 & 1224 & 9 & 11 & 9 \\
\hline Monaldi Archives for Chest Disease & 11 & 32 & 2 & 5 & 2 \\
\hline
\end{tabular}

TP: total number of publications, TC: total citations

\section{Authors' $h$, $g$ and $m$ indexes}

As a result, when the index scores of the authors (Table 4) are evaluated in terms of all three indicators (h-g-m index), the three authors with the highest scores in terms of $h$ and $\mathrm{m}$ index are Raoult $\mathrm{D}$, Colson $\mathrm{P}$, and Rolain JM. The authors with the highest scores in terms of $\mathrm{g}$ index are Hsueh PR and Wang Y.

Productivity and Collaboration Networks of Countries and Institutions

When Figure 3 is examined, the countries marked as dark blue in the figures are the countries that produced more articles, made more international cooperation, and received the most citations. When the geographical maps are examined, it is seen that countries such as China, France, America and England are leading countries.

\section{Total Publication Numbers of Universities}

The most published universities are Huazhong Univ Sci and Technol, Wuhan Univ, Natl Taiwan Univ, Chinese Univ Hong Kong and Aix Marseille Univ (Table 5).

Looking at the graph of the number of publications of the universities, it is seen that the universities in the top five are universities of Chinese origin.

Table 4. Authors' h, g and $m$ indexes (top 20 authors)

\begin{tabular}{lccccc}
\hline Author & TP & TC & h index & g index & m index \\
\hline Raoult D & 10 & 934 & 7 & 10 & 7 \\
Colson P & 9 & 934 & 7 & 9 & 7 \\
Rolain JM & 8 & 944 & 7 & 8 & 7 \\
Hsueh PR & 15 & 441 & 6 & 15 & \\
Ye F & 8 & 221 & 6 & 8 & \\
Wang Y & 14 & 124 & 5 & 11 & \\
Zhao S & 11 & 87 & 5 & 9 & \\
Chowell G & 9 & 296 & 5 & 9 & 5 \\
Zhao Y & 9 & 152 & 5 & 9 & \\
Li YM & 8 & 209 & 5 & 8 & \\
Liu L & 8 & 242 & 5 & 8 & \\
Peng P & 6 & 154 & 5 & 6 & 5 \\
Huang L & 5 & 849 & 5 & 5 & 5 \\
Nicastri E & 5 & 121 & 5 & 5 & 5 \\
Wang L & 9 & 123 & 4 & 9 & \\
Wang X & 8 & 99 & 4 & 8 & 4 \\
Hu Y & 8 & 144 & 4 & 8 & 4 \\
Ko WC & 7 & 379 & 4 & 7 & 4 \\
Liu JY & 6 & 147 & 4 & 6 & 4 \\
\hline
\end{tabular}

Table 5. Publication numbers of universities

\begin{tabular}{lc}
\hline Affiliation & Article \\
\hline Huazhong Univ Sci And Technol & 98 \\
Wuhan Univ & 76 \\
Natl Taiwan Univ & 39 \\
Chinese Univ Hong Kong & 31 \\
Aix Marseille Univ & 28 \\
Cent South Univ & 28 \\
Univ Hong Kong & 26 \\
Shanghai Jiao Tong Univ & 25 \\
Sun Yat Sen Univ & 23 \\
Capital Med Univ & 22 \\
Charite Univ Med Berlin & 22 \\
Guangzhou Med Univ & 22 \\
Xi An Jiao Tong Univ & 22 \\
Zhejiang Univ & 20 \\
Shahid Beheshti Univ Med Sci & 18 \\
Univ Oxford & 18 \\
Fudan Univ & 16 \\
Shandong Univ & 16 \\
Kyoto Univ & 15 \\
Southern Univ Sci And Technol & 15 \\
\hline
\end{tabular}




\section{Country Scientific Production}

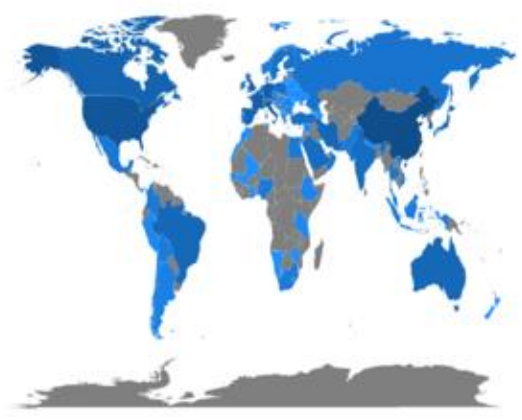

Country Colaboration Map

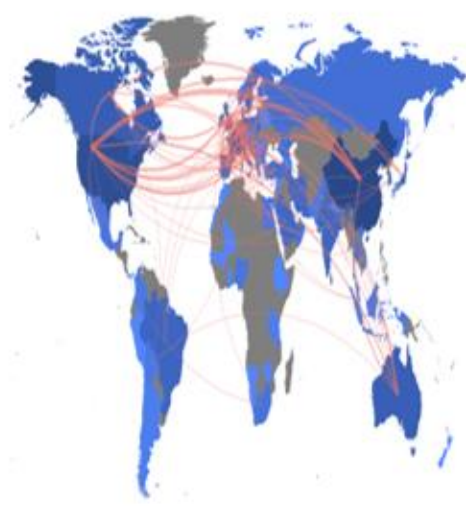

Most Cited Countries

Figure 3. Productive countries, most cited countries and cooperation between countries

\section{Corresponding Authors and Collaboration}

Countries with an MCP rate of $50 \%$ and above are countries with high international cooperation in the field of COVID-19. Belgium, Australia and Canada are among the countries that cross this threshold. MCP rate in Turkey is $16.67 \%$ (Figure 4 ). SCP and MCP rates of the countries are shown in Table 6.

\section{Lotka Law}

Lotka law and the number of articles published by the authors are shown in Table 7. Lotka law predicts that $60 \%$ of the authors contribute with one article, $15 \%$ with 2 articles, and 7\% with 3 articles (38). When articles and authors are examined within the framework of Lotka law, it was seen that $85 \%$ of the authors contributed with one article, $9.5 \%$ of the authors contributed with two articles, $2.5 \%$ of authors contributed with three articles, $\% 0.8$ of the authors contributed with four articles, $\% 0.7$ of the authors

Table 6. SCP and MCP rates of countries

\begin{tabular}{lccccc}
\hline Country & Article & Freq & SCP & MCP & MCP Ratio \\
\hline China & 295 & 0.37532 & 246 & 49 & 0.1661 \\
USA & 99 & 0.12595 & 73 & 26 & 0.2626 \\
Italy & 56 & 0.07125 & 46 & 10 & 0.1786 \\
France & 36 & 0.0458 & 25 & 11 & 0.3056 \\
United Kingdom & 36 & 0.0458 & 20 & 16 & 0.4444 \\
Germany & 21 & 0.02672 & 16 & 5 & 0.2381 \\
Canada & 20 & 0.02545 & 10 & 10 & 0.5 \\
Japan & 19 & 0.02417 & 14 & 5 & 0.2632 \\
Australia & 17 & 0.02163 & 7 & 10 & 0.5882 \\
Brazil & 16 & 0.02036 & 13 & 3 & 0.1875 \\
Korea & 16 & 0.02036 & 15 & 1 & 0.0625 \\
Iran & 14 & 0.01781 & 12 & 2 & 0.1429 \\
India & 13 & 0.01654 & 12 & 1 & 0.0769 \\
Spain & 12 & 0.01527 & 7 & 5 & 0.4167 \\
Saudi Arabia & 9 & 0.01145 & 5 & 4 & 0.4444 \\
Singapore & 8 & 0.01018 & 6 & 2 & 0.25 \\
Belgium & 7 & 0.00891 & 2 & 5 & 0.7143 \\
Poland & 6 & 0.00763 & 5 & 1 & 0.1667 \\
Turkey & 6 & 0.00763 & 5 & 1 & 0.1667 \\
Austria & 5 & 0.00636 & 2 & 3 & 0.6 \\
\hline MCP & &
\end{tabular}

contributed with five articles. The reason why the distribution does not comply with Lotka law is that all relevant publications belong to 2020, and due to the examination of the publications in the eight-month period, the rapid publication process took place in a very short time. As the number of publishing years increases, the distribution is likely to change thanks to the newly published data. In addition, as a natural result of the work of numerous authors in COVID-19 articles, the findings may indicate excessive dispersal. It was understood that the author distribution of COVID-19 articles did not comply with Lotka's law. However, it should be accepted that authors with more than five publications have been deepened in the field of COVID-19 and should be considered as core authors (Figure 5).

A total of seven publications in 787 articles originated in Turkey. Only one of these publications is included in international collaboration. Others are studies based on research results that take place in Turkey. At the time of the study, one study received two citations, two studies received one citation, and the other studies received no citations. Because of this, Turkey data did not appear much in the visuals. One of these studies is review. The other six studies are original articles.

Table 7. Lotka law and the number of articles by the authors

\begin{tabular}{ccc}
\hline Number of Article & Number of Author & Author Rate \\
\hline 1 & 4748 & 0.8580 \\
2 & 528 & 0.0950 \\
3 & 136 & 0.0250 \\
4 & 46 & 0.0080 \\
5 & 39 & 0.0070 \\
6 & 11 & 0.0020 \\
7 & 3 & 0.0010 \\
8 & 12 & 0.0020 \\
9 & 5 & 0.0010 \\
10 & 2 & 0.0000 \\
11 & 1 & 0.0000 \\
13 & 1 & 0.0000 \\
14 & 1 & 0.0000 \\
15 & 2 & 0.0000 \\
\hline
\end{tabular}




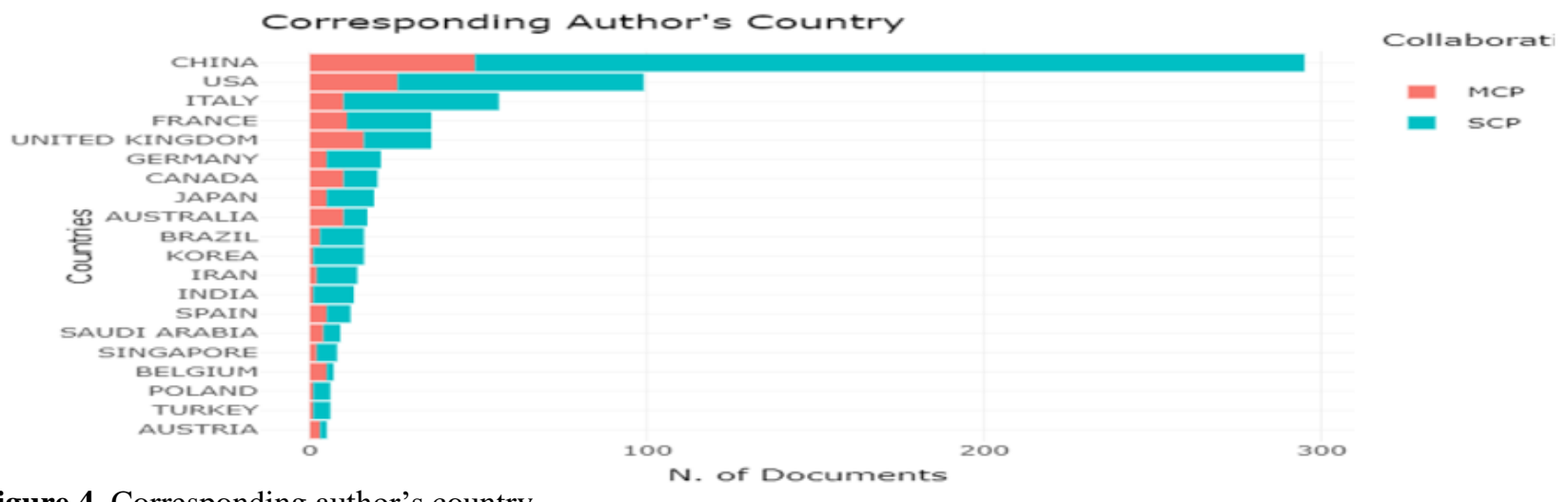

Figure 4. Corresponding author's country

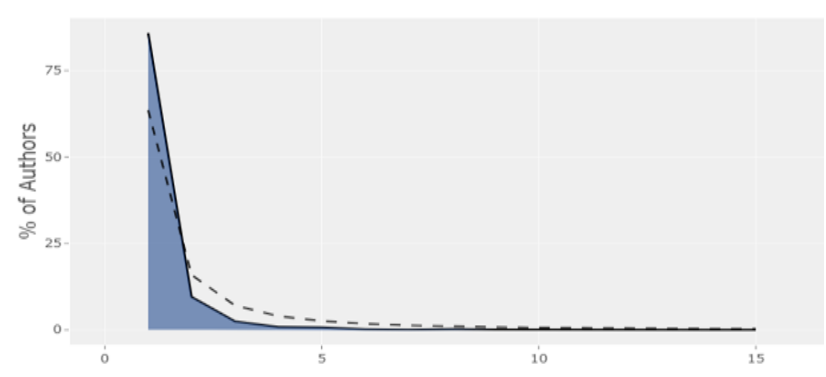

Figure 5. Lotka law

In a review written by Şenturk et al. (39), the authors mentioned the procedures necessary to provide general airway management in thoracic surgery and other anesthesia in COVID-19 patients. In the study of Kilic $\mathrm{M}$ et al. (40), they investigated the presence of SARS-CoV-2 in patients who only consult with sudden sensorineural hearing loss (SSHNL) during the COVID-19 pandemic. In the multicenter study of Kant et al. (41), it was aimed to demonstrate the diagnostic value of thoracic computed tomography (CT) imaging in terms of symptom duration and as a result, they stated that it should be done with chest CT imaging when RT-PCR test cannot be performed or gives negative result. In a multicenter study involving authors from Turkey, the aim of the study was to retrospectively investigate the epidemiological and clinical features, laboratory results, radiological findings and results of COVID-19 in patients with transfusion-induced thalassemia major (TM), thalassemia intermedia (TI) and sickle cell disease (42). In the study of Pinar Senkalfa et al. (43), it was aimed to evaluate the anxiety associated with the COVID-19 pandemic in children with cystic fibrosis (CF) and their mothers. They stated that informing parents of children with CF about COVID-19 via teleconference can reduce anxiety (43). Ucpinar et al. (44) presented the first case of pneumothorax, which is one of the complications that may develop in patients with COVID-19. In the study of Dost et al. (45), they evaluated the knowledge of anesthesiologists and assistants in Turkey about COVID-19 and their attitude towards the strategies and methods of application to be used. Major Clusters and Time Map

\section{Major Clusters}

The Citespace program identified nine significant clusters in terms of co-citation analysis technique. The largest of these clusters is the zero cluster and is named hydroxychloroquine. The silhouette value is used as a measure of whether clusters are identified in a meaningful way. The silhoutte threshold value required for the cluster to be meaningful is 0.60. Each cluster is named in three different ways. The name of the naming algorithm proposed by the inventor of the program is LLR (18). A Landscape View of the Citation Network $(\mathrm{LRF}=3, \mathrm{LBY}=8$ and $\mathrm{e}=2.0)$ The scientific view on the subject above has been produced based on publications for the first eight months of 2020 . The network consisted of 787 articles and 10865 references were analyzed. The network has a modularity value of 0.6468 , which is considered high. This shows that the specializations in the science map are clearly defined in terms of common resource sets. The modularity value is expected to be equal to or greater than 0.6. Mean silhoutte value is desired to be 0.7 and higher (18). A small mean score of 0.313 indicates the presence of many small clusters with very few members. The Citespace software is able to extract small clusters and display clusters with a meaningful dace silhoutte value. The cluster with the youngest clusters and the highest number of publications is the "hydroxychloroquine" cluster. Therefore, clusters that are very small in the relevant program have been removed from the landscape view and analyzed. The differently colored fields indicate when common reference links in these fields appeared for the first time. The program also includes coloring feature of clusters. Each set can be tagged with title terms, keywords, and terms derived from the summary. In the first image, all clusters are shown, and in the second image, small clusters with insignificant silhoutte values are removed from the analysis and visualized. The largest cluster is \#0 hydroxychloroquine (program starts the largest cluster from scratch, (Figure 6).

\section{Time Map}

Looking at the time map, it is understood that all the clusters that are particularly meaningful are very lively and up-to-date. There is no cluster that has lost its vitality. We can agree with this interpretation with a cautious approach. We believe that it is an early comment since the publication period only covers eight months. A clearer interpretation can be made when a study is carried out over the years (Figure 7). There are no data in WoS regarding the publication speed of the articles. However, the full texts of the relevant publications have the date of arrival and the date of acceptance of the article. It has been observed that these periods are relatively brief. 


\section{Word Analysis (Lexical Analysis)}

Word analysis was analyzed with both Bibliometrix and VosViewer software. Bibliometrix software analyzes words by using the title of the article, keywords, abstract and the bibliography of the article. The analysis obtained by using the bibliography of the article is called keyword plus (a feature not found in other software). The words with the highest frequency in the words obtained from the abstracts are COVID, patients, cases disease, SARS-CoV, coronavirus, clinical, infection, severe and respiratory. In other words, the authors mostly preferred these words in the title of the article (Figure 8).

When Figure 9 was examined, it was seen that the words of COVID-19 publications were combined in three main clusters. The most prominent words of the red cluster are pandemic, epidemic, country, spread, and region. The most prominent words of the green cluster are admission, fever, therapy, and year. In the blue set, words such as PCR and specificity are in the foreground (Figures 9 and 10).

\section{DISCUSSION and CONCLUSION}

Science mapping is becoming an important activity for academics working in all disciplines. As the number of publications increases and publications partially deepen, the task of accessing information, analyzing and transferring it to academic platforms becomes more complex. Conceptual structure is the basic themes that science speaks and follows. Intellectual structure is the work with which authors penetrate a scientific community. Social structure is how writers, institutions and countries affect each other. Determination of the conceptual structure, intellectual structure and the social structure have the potential to enable countries and universities to use their scarce resources more profitably. In addition, scientific research areas and resources can be arranged thanks to the motor themes obtained from the thematic development process. Results from science mapping, data visualization, and bibliometric software can also be one of the most rational inputs for policymaking.
First, the variety of topics and subheadings addressed by scientists regarding the COVID-19 crisis is increasing exponentially, indicating that the virus affects our current and future lifestyle on various fronts (46). The effect of COVID-19 on respiratory diseases and infection disciplines needs research that brings new perspectives to the research. Second, the key issues identified serve as a path for practitioners and academics seeking future research.

The biggest limitation of this study is that it examines the bibliometric analysis of COVID-19 publications only in terms of WoS database. Studies in Scopus and other databases were not included in the analysis. In addition, a bibliometric analysis of the first 100 articles with the most citations can be made. Contribution to the health of countries other than Continental Europe, America and China is also worth investigating.

Journals in Scopus and WoS databases are published and reviewed each year to ensure their high quality. This study only used WoS, and this is a limitation. Therefore, future studies need to cover more databases in order to collect more comprehensive data and avoid bias.

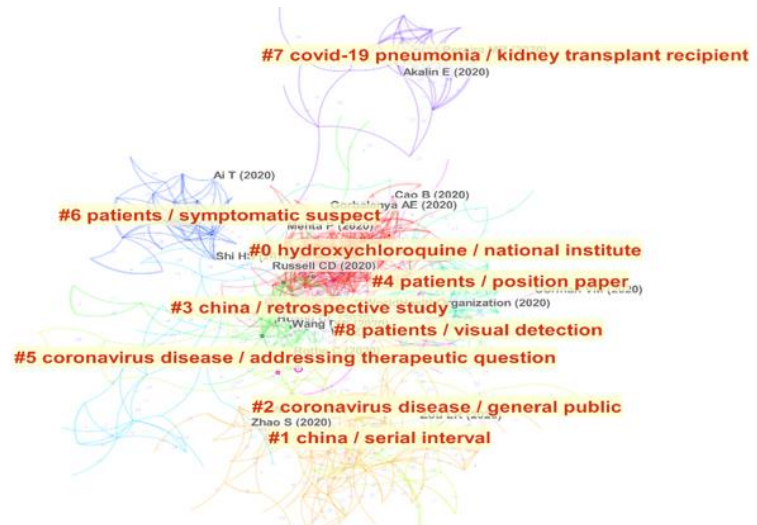

Figure 6. Document co-citation clusters visualization (based on citespace landscape analysis)

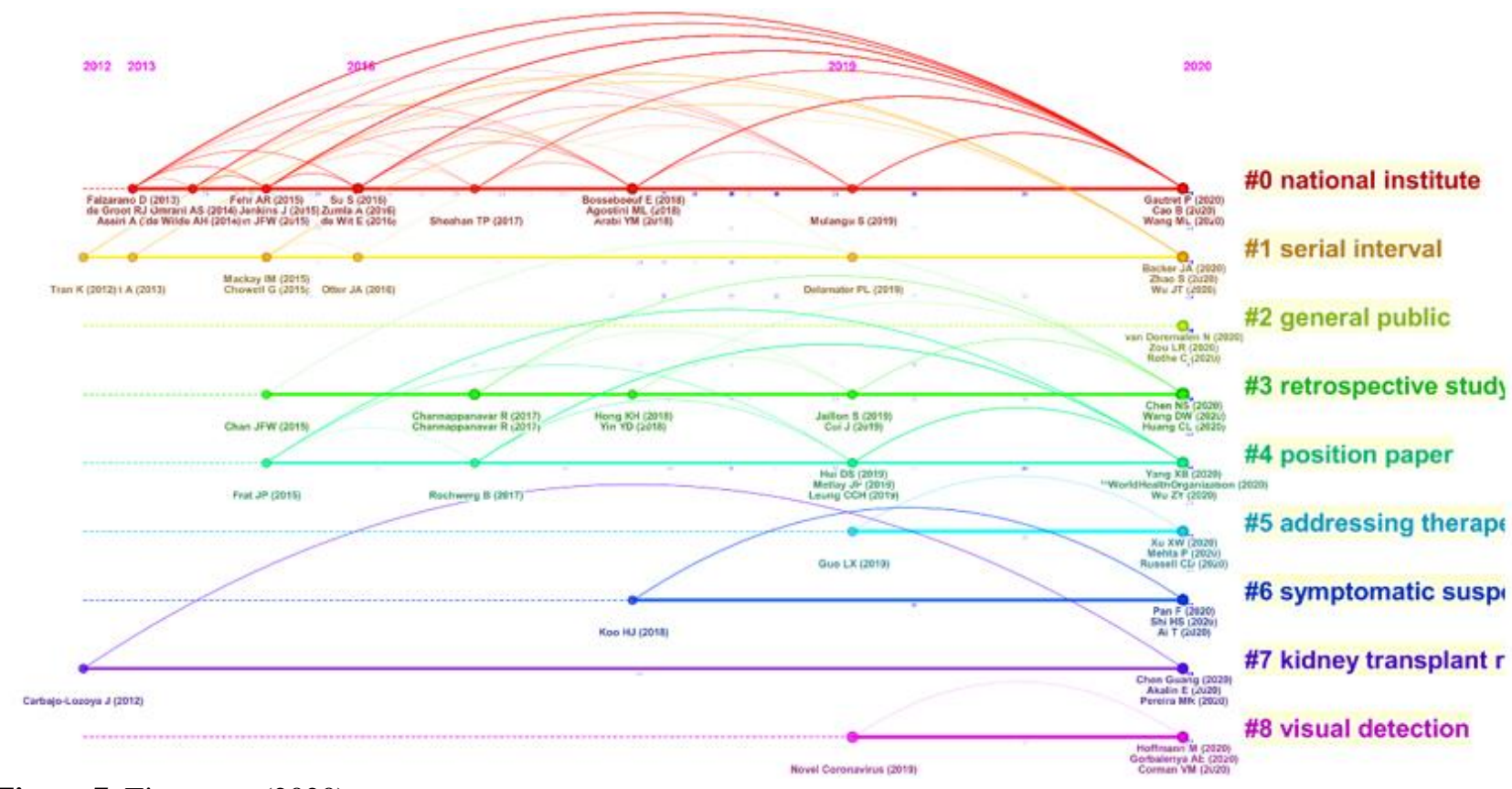

Figure 7. Time map (2020) 
a)
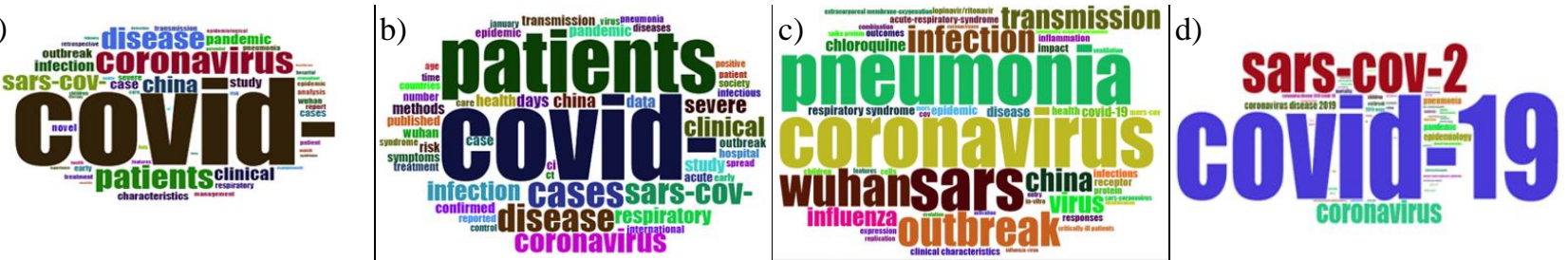

Figure 8. Word trees; a) by article title, b) by summary, c) by keyword plus, d) by keywords

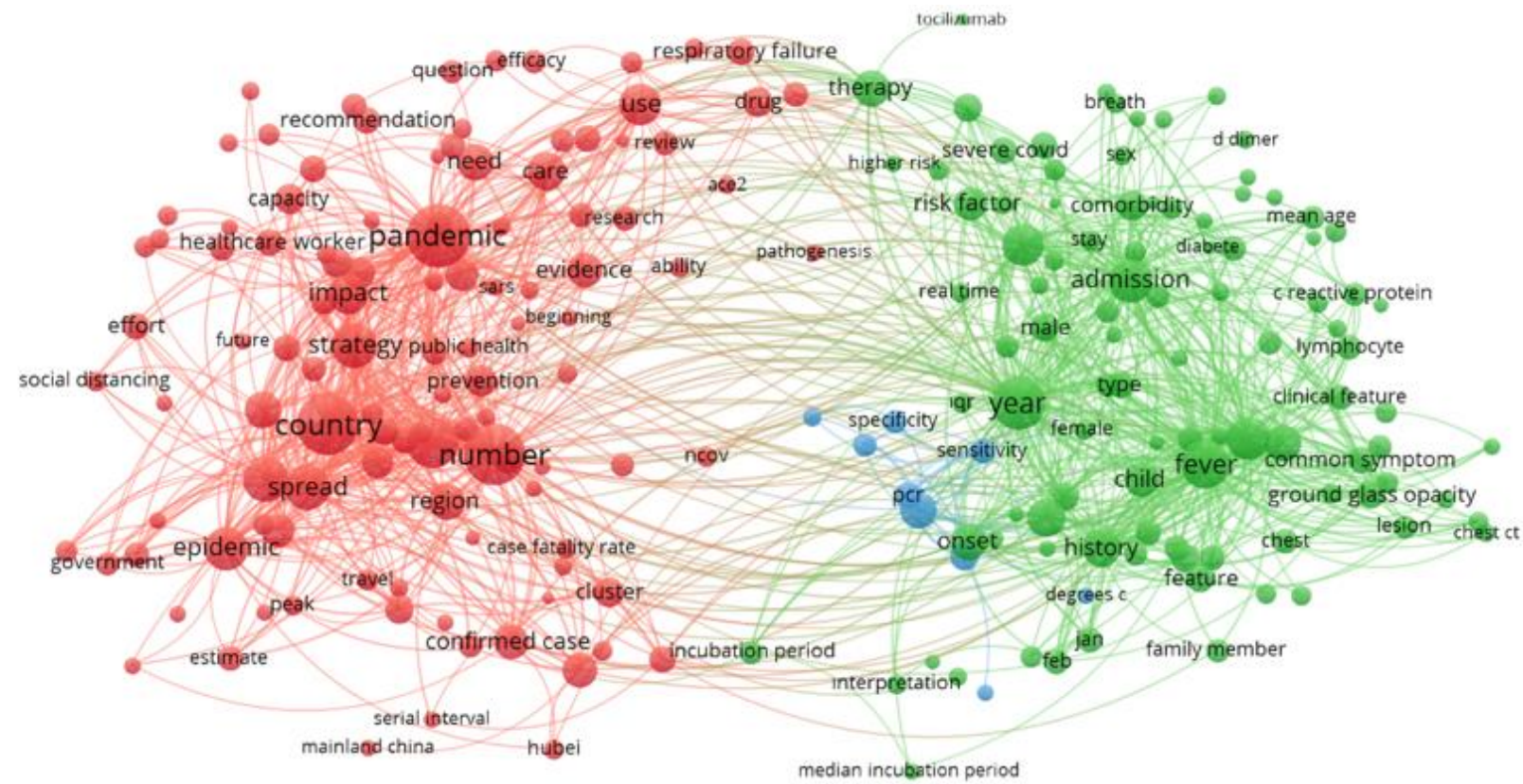

Figure 9. Word mining (VosViewer)

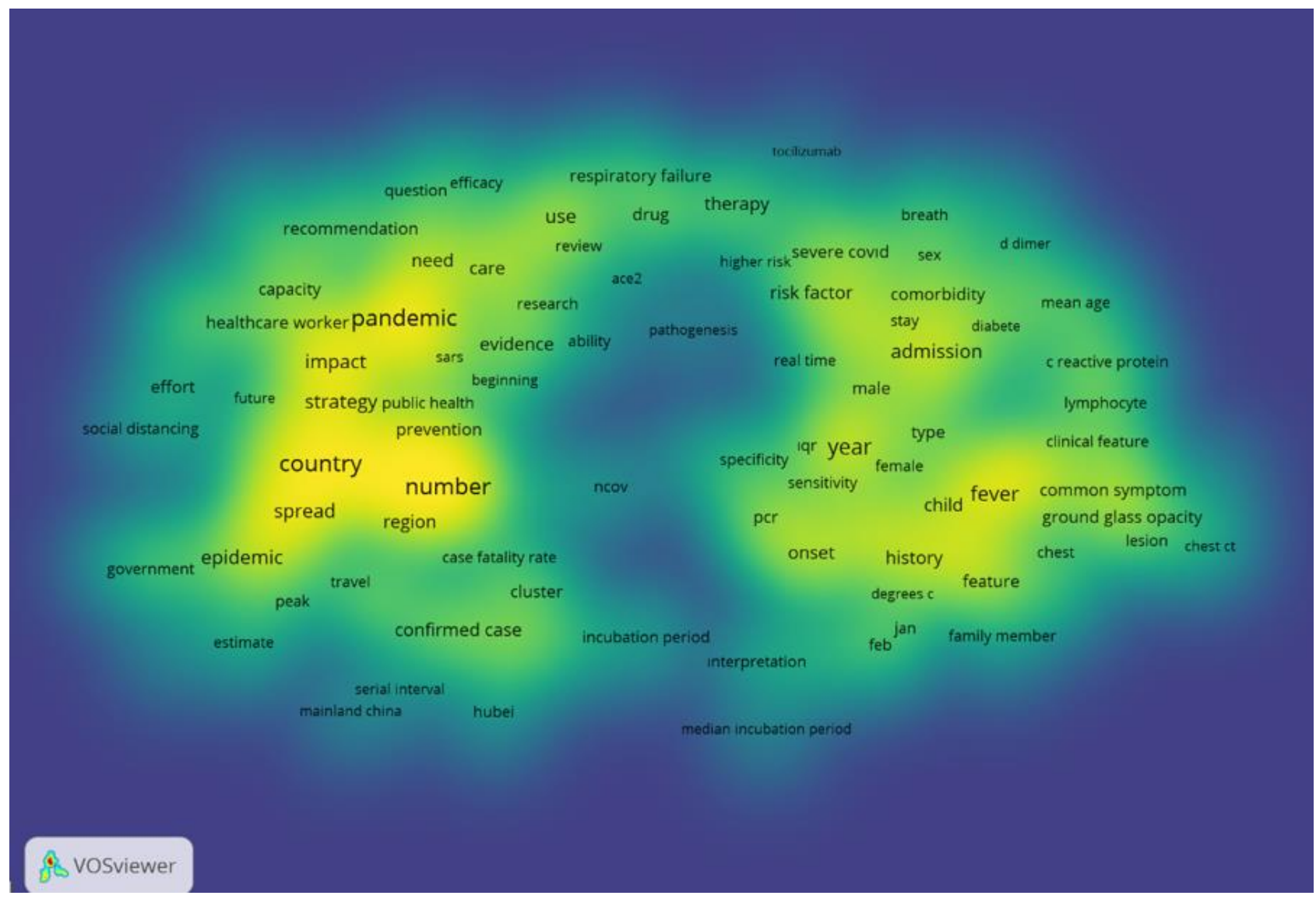

Figure 10. Keyword density map 
Ethics Committee Approval: Since our study was not an experimental study including human or animal subject, ethics committee approval was not required.

Conflict of Interest: None declared by the authors.

Financial Disclosure: None declared by the authors.

Acknowledgements: None declared by the authors.

Author Contributions: Idea/Concept: PYG, MNK; Design: PYG, MNK; Data Collection/Processing: PYG, MNK; Analysis/Interpretation: PYG, MNK; Literature Review: PYG, MNK; Drafting/Writing: PYG, MNK; Critical Review: PYG, MNK.

\section{REFERENCES}

1. Park SE. Epidemiology, virology, and clinical features of severe acute respiratory syndrome -coronavirus-2 (SARS-CoV-2; Coronavirus Disease-19). Clin Exp Pediatr. 2020;63(4):119-24.

2. Lai CC, Wang CY, Wang YH, Hsueh SC, Ko WC, Hsueh PR. Global epidemiology of coronavirus disease 2019 (COVID-19): disease incidence, daily cumulative index, mortality, and their association with country healthcare resources and economic status. Int $\mathbf{J}$ Antimicrob Agents. 2020;55(4):105946.

3. Buruk CK, Tosun İ. SARS-CoV'dan SARS-CoV-2'ye koronavirüsler. In: Özlü T, editor. Göğüs Hastalıkları ve COVID-19. Ankara: Türkiye Klinikleri; 2020. p.15.

4. Murthy S, Gomersall CD, Fowler RA. Care for critically ill patients with COVID-19. JAMA. 2020;323(15):1499-500.

5. Yu Y, Li Y, Zhang Z, Gu Z, Zhong H, Zha Q, et al. A bibliometric analysis using VOSviewer of publications on COVID-19. Ann Transl Med. 2020;8(13):816.

6. Andonie R, Dzitac I. How to write a good paper in computer science and how will it be measured by ISI web of knowledge. Int $\mathrm{J}$ Comput Commun Control. 2010;5(4):432-46.

7. Shang G, Saladin B, Fry T, Donohue J. Twenty-six years of operations management research (1985-2010): authorship patterns and research constituents in eleven top rated journals. Int J Prod Res. 2015;53(20):616197.

8. He X, Wu Y, Yu D, Merigó JM. Exploring the ordered weighted averaging operator knowledge domain: a bibliometric analysis. Int $\mathbf{J}$ Intell Syst. 2017;32(11):1151-66.

9. Huarachi DAR, Piekarski CM, Puglieri FN, de Francisco AC. Past and future of Social Life Cycle Assessment: Historical evolution and research trends. J Clean Prod. 2020;264:121506.

10. Zou X, Vu HL. Mapping the knowledge domain of road safety studies: A scientometric analysis. Accid Anal Prev. 2019;132:105243.

11. Xue W, Li H, Ali R, Rehman RU. Knowledge mapping of corporate financial performance research: A visual analysis using cite space and ucinet. Sustainability. 2020;12(9):3554.

12. Ren XS, Liu YJ. A bibliometric analysis on higher education curricula model. In: 2018 2nd International
Conference on Education, Economics and Management Research (ICEEMR 2018). Atlantis Press; 2018. doi: 10.2991/iceemr-18.2018.183.

13. Hsieh PN, Chang PL. An assessment of world-wide research productivity in production and operations management. Int J Prod Econ. 2009;120(2):540-51.

14. Wang C, Lim MK, Zhao L, Tseng ML, Chien CF, Lev B. The evolution of Omega-The International Journal of Management Science over the past 40 years: A bibliometric overview. Omega. 2020;93:102098.

15. Cobo MJ, López-Herrera AG, Herrera-Viedma E, Herrera F. Science mapping software tools: Review, analysis, and cooperative study among tools. J Assoc Inf Sci Technol. 2011;62(7):1382-402.

16. Aria M, Cuccurullo C. bibliometrix: An R-tool for comprehensive science mapping analysis. J Informetr. 2017;11(4):959-75.

17. van Eck NJ, Waltman L. VOSviewer manual. Leiden: Univeristeit Leiden; 2013.

18. Chen C. CiteSpace II: Detecting and visualizing emerging trends and transient patterns in scientific literature. J Assoc Inf Sci Technol. 2006;57(3):359-77.

19. Cobo MJ, López-Herrera AG, Herrera-Viedma E, Herrera F. SciMAT: A new science mapping analysis software tool. J Assoc Inf Sci Technol. 2012;63(8):1609-30.

20. Perannagari KT, Chakrabarti S. Analysis of the literature on political marketing using a bibliometric approach. J Public Aff. 2020;20(1):e2019.

21. Duque P, Cervantes-Cervantes LS. University Social Responsibility: a systematic review and a bibliometric análisis. Estudios Gerenciales. 2019;35(153):451-64.

22. Firat S, Kurutkan MN, Orhan F. Sağlık politikası konusunun bilim haritalama teknikleri ile analizi. In: Kurutkan MN, Orhan F, editors. Sağlık politikası konusunun bilim haritalama teknikleri ile analizi. Istanbul; Iksad Publications; 2018. p.28-73.

23. Serafin MJ, Garcia Vargas GR, del Pilar GarcíaChivita M, Caicedo M, Correra JC. Cyberbehavior: A bibliometric analysis. Annu Rev Cyber Therapy Telemed. 2019;17(1):17-24.

24. Kamdem JP, Duarte AE, Lima KRR, Rocha JBT, Hassan W, Barros LM, et al. Research trends in food chemistry: A bibliometric review of its 40 years anniversary (1976-2016). Food Chem. 2019;294:44857.

25. Chan TM, Kuehl DR. On lampposts, sneetches, and stars: a call to go beyond bibliometrics for determining academic value. Acad Emerg Med. 2019;26(6):688-94.

26. Pinto M. Viewing and exploring the subject area of information literacy assessment in higher education (2000-2011). Scientometrics. 2015;102:227-45.

27. Herrera-Viedma E, López-Robles JR, Guallar J, Cobo MJ. Global trends in coronavirus research at the time of COVID-19: A general bibliometric approach and content analysis using SciMAT. Prof de la Inf. 2020;29(3):e290322.

28. Zhou Y, Chen L. Twenty-year span of global coronavirus research trends: A bibliometric analysis. Int J Environ Res Public Health. 2020;17(9):3082.

29. Kaya M, Erbay E. Global trends of the researches on COVID-19: A bibliometric analysis via VOSviewer. Journal of Ankara Health Sciences. 2020;9(2):201-16. 
30. Ram S. Coronavirus research trends: A 50-year bibliometric assessment. Sci Technol Libr. 2020;39(2):210-26.

31. Nasab FR, Rahim F. Bibliometric analysis of global scientific research on SARS-CoV-2 (COVID-19). MedRxiv. 2020. doi: 10.1101/2020.03.19.20038752.

32. clarivate.com [Internet]. Web of Science. Explore Web of Science Core Collection indices. [Cited: $2020 \mathrm{Nov}$ 25]. Available from: https://clarivate.com/webofscienc egroup/solutions/web-of-science-core-collection/

33. Falagas ME, PitsouniEI, Malietzis GA, Pappas G. Comparison of PubMed, Scopus, Web of Science, and Google Scholar: strengths and weaknesses. FASEB J. 2008;22(2):338-42.

34. Janik A, Ryszko A, Szafraniec M. Scientific landscape of smart and sustainable cities literature: A bibliometric analysis. Sustainability. 2020;12(3):779.

35. Bornmann L, Daniel HD. What do we know about the h index? J Assoc Inf Sci Technol. 2007;58(9):1381-5.

36. Egghe L. Theory and practise of the g-index. Scientometrics. 2006;69:131-52.

37. Harzing AW. Reflections on the h-index. Business\&Leadership 2012;1(9):101-6.

38. Sudhier KP. Lotka's law and pattern of author productivity in the area of physics research. DESIDOC J Inf Technol. 2013;33(6):457-64.

39. Şentürk M, El Tahan MR, Szegedi LL, Marczin N, Karzai W, Shelley B, et al. Thoracic anesthesia of patients with suspected or confirmed 2019 novel coronavirus infection: preliminary recommendations for airway management by the European Association of Cardiothoracic Anaesthesiology Thoracic Subspecialty Committee. J Cardiothorac Vasc Anesth. 2020:34(9);2315-27.
40. Kilic O, Kalcioglu MT, Cag Y, Tuysuz O, Pektas E, Caskurlu H, et al. Could sudden sensorineural hearing loss be the sole manifestation of COVID-19? An investigation into SARS-CoV-2 in the etiology of sudden sensorineural hearing loss. Int $\mathrm{J}$ Infect Dis. 2020;97:208-11.

41. Kant A, Kostakoğlu U, Atalar S, Erensoy Ş, Sevimli T, Ertunç B, et al. The relationship between diagnostic value of chest computed tomography imaging and symptom duration in COVID infection. Ann Thorac Med. 2020;15(3):151-4.

42. de Sanctis V, Canatan D, Corrons JLV, Karimi M, Daar S, Kattamis C, et al. Preliminary data on COVID19 in patients with hemoglobinopathies: A multicentre ICET-A study. Mediterr J Hematol Infect Dis. 2020;12(1):e2020046.

43. Pınar Senkalfa B, Sismanlar Eyuboglu T, Aslan AT, Ramaslı Gursoy T, Soysal AS, Yapar D, et al. Effect of the COVID-19 pandemic on anxiety among children with cystic fibrosis and their mothers. Pediatr Pulmonol. 2020;55(8):2128-34.

44. Ucpinar BA, Sahin C, Yanc U. Spontaneous pneumothorax and subcutaneous emphysema in COVID-19 patient: Case report. J Infect Public Health. 2020;13(6):887-9.

45. Dost B, Koksal E, Terzi Ö, Bilgin S, Ustun YB, Arslan HN. Attitudes of anesthesiology specialists and residents toward patients infected with the novel coronavirus (COVID-19): A national survey study. Surg Infect (Larchmt). 2020;21(4):350-6.

46. Verma S, Gustafsson A. Investigating the emerging COVID-19 research trends in the field of business and management: A bibliometric analysis approach. J Bus Res. 2020;118:253-61. 